\title{
2. A Radical Prequel: Historicising the Concept of Gendered Law in Australia
}

\author{
Ann Genovese ${ }^{1}$
}

\begin{abstract}
Anniversaries are about remembering - about reiterations and critiques, as well as about reflections and celebrations. In this way, an anniversary essay about the Commonwealth Sex Discrimination Act 1984 (SDA) is an invitation to think historically from different purviews of the past. What I would like to consider therefore in response to such an invitation, as a historian of legal ideas, is not a story about the legislative process in making the Act a reality or a story of the contests and challenges to its subsequent legal meanings. Instead, what I would like to offer to this collection is a prequel: a story of how it became possible to use gender as a conceptual frame for thinking about law in Australia - as the SDA exemplifiesand how that history exposes an experience of radical, countercultural feminist praxis that is often hidden by, but constitutive of, the more familiar teleological stories of feminisms, and of law itself.
\end{abstract}

\section{'Gender: A Useful Category for Historical Analysis'}

In considering how to approach historicising the concept of gendered law in Australia in this way, it is worth reflecting on the fact that it was not until the mid-1980s that gender was theorised, let alone operationalised, as a conceptual category in law, history or other disciplinary traditions. For historians, one of the most influential essays that argued for a theoretical approach to using gender in ways that went beyond descriptive or causal techniques was US historian and theorist Joan Wallach Scott's 'Gender: a useful category for historical analysis' in the American Historical Review. Scott suggested 'we must constantly ask not only what is at stake in proclamations or debates that invoke gender to explain or justify their positions but also how implicit understandings of

1 I thank Ann Curthoys and Margaret Thornton for engagement and dialogue with the historiographical and jurisprudential arguments offered here, as well as with the historical content. I also thank the two reviewers for their helpful clarifications. 
gender are being invoked and reinscribed' ${ }^{2}$ This is particularly important and useful, Scott argues, for thinking through how representations about, and also made by, women are often re-inscribed as normative concepts within discourses, and how that process then 'limits and contains their metaphoric possibilities'. These limits, as has been well understood in much scholarship since then, are often predetermined by the inherent binary oppositions within Enlightenment thought, re-inscribed through particular doctrinal givens. ${ }^{3}$ The task for historians, Scott contended, was nevertheless specific: to refuse to accept those normative concepts and languages, exposed through the archive, as anything but the product of social contest. Through such a refusal, what could be opened up are the spaces that lie between the processes, languages or structures that overwrite and describe concepts in the first place. This enables some room for human agency in normative discourse and therefore suggests rather than forecloses the possibility of change. From this perspective, asking questions about how concepts (such as gender) developed within the legal praxis of a country such as Australia in the immediate past has the potential to be useful in the present, as they can be directed towards 'the possibility for negation, reinterpretation, the play of metaphoric invention and imagination'. ${ }^{4}$

Thinking about Scott's 1986 essay is important for this prequel for two reasons. The first reason is this key question about centralising gender as a category of analysis. Scott's 'Gender' essay is contemporaneous with the SDA's genesis; it reminds us, as noted already, that the mid to late 1980s marks a key moment in the development of thinking about how gender operates normatively in society. To the earlier focus of 'writing women in' (be it to historical narrative or legislative instruments) was now added an interest in the ways in which conceptual categories (such as discrimination) were constructed and perpetuated. ${ }^{5}$ As others in this volume and elsewhere attest in their analyses of the emergence of the SDA in Australia - but for one example - these conceptual concerns were, and remain, clearly evident. ${ }^{6}$ Scott's theorising of gender therefore refracts the content of both a legislative instrument such as the $S D A$ and its political context, and makes an important reiteration that the mid-1980s was an epoch

\footnotetext{
2 Joan W. Scott, 'Gender: A useful Category of Historical Analysis' (1986) 91(5) American Historical Review 1053, 1074.

3 In that same year, Margaret Thornton made a similar case contributing to the development of feminist jurisprudence in this country: Margaret Thornton, 'Feminist jurisprudence: Illusion or Reality?' (1986) 3 Australian Journal of Law \& Society 5.

4 Scott, 'Gender' 1067.

5 For general examples, see: Genevieve Lloyd, The Man of Reason: 'Male' and 'Female' in Western Philosophy, Methuen, London, 1984; Catherine Mackinnon, Feminism Unmodified: Discourse on Life and Law, Harvard University Press, Cambridge, Mass., 1987; Carol Smart, Feminism and the Power of Law, Routledge, London, 1989; Elizabeth Grosz, 'The In(ter)vention of Feminist Knowledges' in Barbara Caine, E. A. Grosz and Marie de Lepervanche (eds), Crossing Boundaries: Feminism and the Critique of Knowledges, Allen \& Unwin, Sydney, 1988.

6 See Sawer, Magarey, Thornton and Luker, Ronalds and Ryan, this volume.
} 
in which earlier manifestations of thinking about the state's construction of women, and its response to discrimination based on sex (be it in Australia, the United Kingdom, Europe or the United States), shifted.

The second reason - and the one that primarily concerns me in this chapteris a question of interrogating politico-legal questions from the traditions offered by critical history. This tradition-as argued by Scott and of course Foucault and others - is to think about how concepts change and to look for ways of engaging with the process of change beyond single origins. As Scott identified, this involves interrogating a range of different, yet intermingled, political, cultural and intellectual trajectories. This suggests a slightly different history from the other stories of the Act's passage included in this book, which cover the predominant and more chartered territory of understanding how feminists, through WEL and within the state in the 1970s and 1980s, argued for the legislative right to be equal (as Jocelynne Scutt described it, in 1988). ${ }^{7}$ The specific causative history of the SDA is importantly very much about the relationship between WEL's focus on making sex discrimination politically visible from 1972 onwards and a state at the high point of its commitment to legislating against disadvantage, as Marian Sawer has made very clear. ${ }^{8} \mathrm{My}$ point, however, is that there are other histories to remember here too. One of these - complementary to those offered in this book-I want to bring to light in this spirit of disrupting a fixed historical gaze, or a belief in single origins, inhered in problematic ways in normative concepts.

This other history involves traditions that ran alongside yet in partnership with those in WEL: Marxism and, less frequently identified in stories about law, radical libertarianism with a commitment to situational exposure of harms to women in the criminal justice system. How these other traditions within feminism met and influenced a nascent Australian feminist legal praxis is my focus. It is a story that centres on the emergence of the Feminist Legal Action Group (FLAG), a group that took gender as a concept seriously and that emerged during the maelstrom of political-cultural radicalism that preceded the passing of the SDA in 1984.

This might seem an esoteric or unorthodox contribution, or indirectly related, to a collection dedicated to reflection about this important piece of Australian legislation. This could even be exacerbated for some by my commitment to write about law using the theory and method of critical history. If, however, we want to continue to take seriously the question of gender for law, we cannot resort to

7 Jocelynne Scutt, 'Legislating for the Right to be Equal: Women, the Law and Social Policy' in Cora Baldock and Bettina Cass (eds), Women, Social Welfare and the State in Australia, Allen \& Unwin, Sydney, 1988. See also Jenny Morgan, 'Women and the Law' in Refractory Girl Collective (eds), Refracting Voices: Feminist Voices from Refractory Girl, Southwood Press, Sydney, 1993.

8 Sawer, this volume. 
descriptive analysis of our past, for gender does not reside in our past-legal or otherwise - in an assumed position of liberal privilege. We should also not become caught in the trap of a historical presbyopia, which Margaret Thornton, in a 2004 essay about crises in feminist legal thinking, describes as the inevitable loss of ability by individuals or communities to focus on what is nearest to them, in all its messy dimensions. ${ }^{9}$ In offering this other history - this prequel about gender as a concept for feminist legal praxis - I want to suggest, instead, that there are always subsumed or forgotten spaces in feminist cultural politics that can be of value when considering how to engage with the SDA today, as these spaces carry the possibilities of re-inscription or resistance beyond the normative boundaries of the law itself.

\section{Discrimination and Australian Laws}

It is important to acknowledge at the outset that the $S D A$ was not without immediate legislative predecessors. Federally, the Commonwealth had enacted the Racial Discrimination Act in 1977, as well as testing its constitutional reliance on UN treaties and conventions, and hence its validity, in Koowarta $v$ BjelkePetersen. ${ }^{10}$ At the State level, there had been of course legislative instruments enacted (the ill-fated Prohibition of Discrimination Act 1966 [SA], as well as the more successful Sex Discrimination Act 1975 [SA], the Anti-Discrimination Act 1977 [NSW] and the Equal Opportunity Act 1977 [Vic.]), which also attempted to grapple in law with the paradox of equality as exclusion. ${ }^{11}$ The language in these predecessors to the $S D A$ reflected a concern present in political culture in Australia at the time: a principle of equality understood as opportunity that emerged from the political rubric of trade unionism and spilled into other areas of political contestation. ${ }^{12}$ These earlier instruments - unsurprisingly perhaps because of that foundation in industrial politics - were very much about addressing the effects of discriminatory conduct as the result of workplace exclusion. (That language is clearly replicated in the SDA and continues to define

\footnotetext{
9 Margaret Thornton, 'Neoliberal Melancholia: The Case of Feminist Legal Scholarship' (2004) 20 Australian Feminist Law Journal 7.

$10 \quad$ (1982) 34 ALR 417.

11 Margaret Thornton, The Liberal Promise: Anti-Discrimination Legislation in Australia, Oxford University Press, Melbourne, 1990, p. 36.

12 See Marian Sawer, Making Women Count: A History of the Women's Electoral Lobby in Australia, UNSW Press, Sydney, 2008, p. 51; Elizabeth Reid and Denis Altman, Equality: The New Issues, Fabian's Winter Lecture Series: Equality under Labor, Victorian Fabian Society, Melbourne, 1973. This point is fully developed in Marian Sawer, The Ethical State?, Melbourne University Press, Carlton, 2003. This idea of equality was in circulation therefore beyond women's campaigns for justice. It can be seen as deployed strategically, for example, in the 1967 referendum by the Federal Council for the Advancement of Aborigines and Torres Strait Islanders (FCAATSI). See Bain Attwood and Andrew Markus, The 1967 Referendum: Race, Power and the Australian Constitution, Second edition, Aboriginal Studies Press, AIATSIS, Canberra, 2007.
} 
its use and limits, as Sara Charlesworth has argued). ${ }^{13}$ There was also as part of that material focus an intended educative function - that law could lead social change in relation to work practices by example, and by coercion if necessary. What was distinct about the $S D A$, unlike these legislative predecessors, was that its framers and champions - women such as Susan Ryan - also sought for the first time to cast it as resolutely embodied. This focus ensured that the incipient legislative language of discrimination was confronted by a specifically feminist legal critique that could be articulated by the mid-1980s, through the indirect discrimination and sexual harassment provisions of the Act.

How had this happened? Partly, through the experience of lawyers working with feminist lobby groups in bringing cases to the anti-discrimination agencies in their respective States, as under the existing legislative schemes there was a growing understanding of what the possibilities and limits of discrimination could mean when incorporated within the conceptual framework of law. The campaigns by the Women's Trade Union Commission and the Working Women's Charter to bring to public notice the indirect discrimination against migrant women workers by Australian Iron and Steel are a case in point. The campaigns (which culminated in the testing of the NSW legislative scheme by the NSW Anti-Discrimination Board in Nadjovska $v A I$ \& $S$ in $1985,{ }^{14}$ leading to a decision by the High Court in $A I \& S v$ Banovic in 1989) ${ }^{15}$ had made clear the need for more specific indirect discrimination provisions, based on recognising barriers to women's advancement at work, because of their circumscribed choices elsewhere. Perhaps more importantly for the historical narrative told here - intended to be distinct but complementary to that of the history of equal rights in work - are the hard-fought-for provisions that identified sexual harassment as a form of discriminatory practice. The NSW case of $O^{\prime}$ Callaghan $v$ Loder - although the plaintiff was ultimately unsuccessful - did result in an Australian tribunal identifying for the first time, albeit problematically, that sexual harassment could be understood as a form of discrimination. ${ }^{16}$ The critique of the reasoning in the decision, however, was important, as it raised

13 Charlesworth, this volume.

14 (1985) EOC 92-140.

15 (1989) 168 CLR 165. See also Rosemary Hunter, Indirect Discrimination in the Workplace, Federation Press, Leichhardt, NSW, 1992, p. 184; Women's Trade Union Commission, Women's Unions, Booklet, Women's Trade Union Commission, Sydney, 1976; The First Ten Years of Sydney Women's Liberation Collection, Mitchell Library, Sydney (hereafter, ML), 388/81.

16 O'Callaghan $v$ Loder (1984) EOC 92-024 (NSW EOT). Justice Jane Mathews defined sexual harassment as 'occurring where a person is "subjected to unsolicited and unwelcome sexual conduct by a person who stands in a position of power in relation to him or her" or must have been accompanied by (tangible) adverse employment consequences to the complainant, such as dismissal or reduction in hours worked' (at 505, 506). This amounted to less favourable treatment of a person on the ground of their sex, when compared with a person of the opposite sex, in similar circumstances. In the preceding decision regarding interpretation of the NSW Act (1984, EOC 92-023), Mathews J made it clear that jurisprudentially she was reliant on North American cases, which made it explicit that harassment based on women's embodiment was an 'unwelcome feature of employment' (as per s. 25 [2]). At 75, 505, she noted that intangible effects were enough to invoke 
questions about the need for how power is used by men against women in workplaces to be seen not only as a question of employment hierarchy, but as a question of gender - a question that was open for vigorous debate in the subsequent legislation. ${ }^{17}$ The sexual harassment provision in the SDA (section 28A) was premised therefore on the idea that there should be a category of harm arising from women's embodied experience, although it was phrased in gender-neutral language and did reiterate a key fiction of liberal legalism that standards of reasonableness are objectively neutral. ${ }^{18}$ Nevertheless, the political intent and context of this provision reflected a genuine shift in thinking about 'discrimination', which was different from the applied language of opening up opportunities that circulated in political rubric of the broad left in Australia at the time, and that feminists were now applying to the case of women's equality. This shift was about thinking how to use law to combat its own constructions and limitations of sexed bodies, rather than seeing law only as a straightforward means of engaging in state reform in order to achieve equal measures, and was about the relationship between feminist politics and legal practitioners, and the development of a subset between the two.

\section{Feminism, Marxism and Law}

Kathleen Lahey has noted of North American feminist theorising about law in the 1970s that it was an 'uncatalogued item, a yet to be recognised experience' ${ }^{19}$ This was mirrored, to greater and lesser degrees, in the Australian context during the same period. Although Joan Scott's point that gender remains a constantly renegotiated value in normative constructions and repressions can be aptly applied to Australian politics in the 1970s, this conscious questioning of gender was slower to be identified within law than in other fields of life and work. One reason for this was that there were fewer women participating in the law in the early 1970s. As Jane Mathews has argued: 'When I went to law school

the section and made clear that there was to be a factual/contextual examination of actions that lead to detriment that encompassed bodily harm or perceived harm. The critique of the judgment, however, rested on the objective test of whether the employer should have realised that their approaches were unwelcome.

17 See Thornton, The Liberal Promise, pp. 58-61. For discussion of this ruling in conjunction with existing NSW provisions and debates, see Gail Mason and Anna Chapman, ‘Defining Sexual Harassment: A History of the Commonwealth Legislation and its Critiques' [2003] Federal Law Review 6 - especially their reflection on the contemporaneous critique of the judgment. The interaction between Australian and US feminist legal scholars and activists is of course important here, noting, however, the distinctiveness of the Australian political context: see Catharine A. Mackinnon, Sexual Harassment of Working Women, Yale University Press, New Haven, Conn., 1979.

18 SDA, s. 28A. See Mason and Chapman ('Defining Sexual Harassment') for an overview of this point and the subsequent critique regarding amendment.

19 Kathleen Lahey, 'Until Women Themselves Have Told All That They Have To Tell' (1985) 23 Osgoode Hall law Journal 519. 
at the end of the fifties and early sixties, there were very few female students indeed... But the 1970s saw a steady and ultimately dramatic increase in the number of women law students. ${ }^{20}$

Adding women to law was a breakthrough for 'getting equal' politics - a breakthrough for Mary Wollstonecraft's and later feminists, incorporating John Stuart Mill's articulation that education for women enables and promotes social betterment for the individual and the society. ${ }^{21}$ Adding feminism to law is, however, something quite different.

The early engagement of feminists with the law in the 1970s did not occur in a straightforward way. For some, engaging with law-even around significant questions of abortion law reform - was problematic, as it suggested a relationship to the state or police that was antithetical to radical politics at the time. For others, it was about using law strategically to effect specific, material change for women. ${ }^{22}$ This recognition of law's role - as part of the state-came in two forms. One was the conscious lobbying of grassroots groups, often drawn from a more radical base than WEL, asking lawyers to assist in their campaigns to lobby the government for provisions of resources for women-specific services (especially domestic violence refuges and medical services). ${ }^{23}$ The second, as already mentioned, was the more strenuous use of law as a lobby or reform vehicle for state intervention, as mobilised by WEL. This kind of attention, however, to the instrumental function of law as it directly translated to the organisation of holistic legal services or practitioner advice, no matter how crucial, was in many ways a continuation of earlier periods of feminist-identified campaigning around equal pay, property rights or social security provisions. ${ }^{24} \mathrm{It}$ was a turn to law by feminist groups, not a specifically 'feminist legal' response to identified harms, and did not necessarily engage an analytical focus of the law's epistemological construction of women as legal subjects, or therefore of how gender operated in law.

By 1975 there was, however, the beginning of a theorised recognition of the barriers preventing the emergence of a legal identity for women, which would

\footnotetext{
20 Jane Mathews, 'Women in the Law' (1991) 41 Refractory Girl 27.

21 Mary Wollstonecraft, A Vindication of the Rights of Woman, Penguin Books, Harmondsworth, UK, 1982 [1792]. See also Wendy Brown, 'Tolerance as Supplement: The "Jewish Question" and the "Woman Question"', Regulating Aversion: Tolerance in the Age of Identity and Empire, Princeton University Press, NJ, 2008.

22 I thank two of my reviewers for pointing out these opposing nuances in the general claim.

23 This is not to suggest that 'lawyers' and 'women's groups' were always distinct, but, as noted by FLAG in 1981, there was a 'dearth of lawyers with feminist sympathies'. See Kim Ross, 'F.L.A.G.' (1979) 4(3) Legal Services Bulletin 123. For examples of the kind of engagement suggested here, see: Ann Genovese, The Battered Body: A Feminist Legal History, PhD thesis, University of Technology, Sydney, 1998, pp. 152-5, $<$ utsescholarship.lib.uts.edu.au/dspace/handle/2100/276>

24 See generally: Marilyn Lake, Getting Equal: The History of Australian Feminism, Allen \& Unwin, St Leonards, NSW, 1999; Patricia Grimshaw, Marilyn Lake, Ann McGrath and Marian Quartly, Creating a Nation 1788-2007, Second edition, API Network, Perth, 2007.
} 
suggest gender as a conceptual basis for extending the existing legislative understanding of discrimination. An incipient Marxist feminism provided the foundation for a critique of law as a product of capitalism qua patriarchy that was allegedly committed to equality for all, yet which operated overtly to prevent women from enjoying equitable protection for their legal injuries and legal entitlements. In an indirect fashion, by recognising the operation of laws in Australia that used sex as the basis for their determination, on matters such as the right to a minimum wage, custody of children or legal abortion, some lawyers, who also were part of the women's liberation movement, such as Deirdre O'Connor, started to make more critical claims for women's legal equality and consequently their autonomy. O'Connor, in a submission to the Sydney Women's Commission in 1975, envisaged this process in the same language as that used by WEL, through direct agitation by women, in terms of campaigning directly against discriminatory legislation, as well as campaigning for sex discrimination laws 'either as a basic constitutional guarantee or as a normal legislative enactment' ${ }^{25} \mathrm{O}^{\prime}$ Connor also tried, however, to problematise the question of reliance by the women's liberation movement, or WEL, on law reform 'as a major weapon in their struggle' ${ }^{26}$ As she explained in her paper:

The legal system reflects and reinforces the social system in which it operates. Marx went so far as to assert that as law was a reflection of the economic base of society, it was incapable of being innovative except to the extent that laws could react back on the base, and impede change and/or progress. Even without a total adoption of the Marxian view, it must be conceded that in every area legal change has followed rather than promoted social and economic change. ${ }^{27}$

This Marxist foundation, bolstered by supportive Labor politics of the period committed to understanding disadvantage as socially embedded, enabled important material developments in relation to Australian women's experience within existing law, as well as gaining better access to its protections (such as the aforementioned state-based discrimination legislation).$^{28}$ It did not yet embody the idea of gendered discrimination that galvanised politics in the 1980s.

\footnotetext{
25 Deirdre O'Connor, Should the Women's Movement rely on law reform as a major weapon in their struggle?, Unpublished paper, Women's Commission, Sydney, 1975, p. 41; The First Ten Years of Sydney Women's Liberation Collection, ML 388/81.

26 This intellectual debate between feminists who advocated reform and those who did not has been legion, and is still constantly negotiated. See: Margaret Thornton, 'Feminism and the Contradictions of Law Reform' (1991) 19 International Journal of the Sociology of Law 453 and more recently, Susan Armstrong, 'Is Feminist Law Reform Flawed? Abstentionists \& Sceptics' (2004) 20 Australian Feminist Law Journal 43.

27 O'Connor, Should the Women's Movement rely on law reform as a major weapon in their struggle?, p. 41.

28 For an assessment of these early changes, see Anne Maree Lanteri, 'Woman and The Law' in Jan Mercer (ed.), The Other Half: Women in Australian Society, Penguin, Ringwood, Vic., 1975
} 
The politics of feminism and the interactions between the increase of women law students throughout the 1970s and their exposure to the politics and ideas of their time, however, helped give shape to this emergent feminist jurisprudence. This is not to suggest that all female law students or even lawyers who wanted to think about questions such as equality or disadvantage identified as feminist. Nevertheless, it is important to acknowledge that for those who did, their legal education remained normatively bound. ${ }^{29}$ As such, ideas about law were informed as much by conversation about the role of the state and other prevailing questions of governance, in other disciplines and in other grassroots campaigns - some of which did not originate in the politics of WEL or women's liberation.

\section{Left Lawyers and Libertarians}

Political historian John Chesterman has argued that the amorphous nature of left-wing political cultures in Australia in the 1970s was linked by one common theme: the 'rejection or at least the appearance of rejection, of mainstream culture'.$^{30}$ This is significant. Mainstream culture itself became a site of protest and, for young legal academics and law students, men and women, such protestor confrontation - was manifested through a critique of the manipulation of people by authority and the lack of access to the law for those on low incomes. O'Connor's Marxist analysis of law in 1975 clearly showed this and was a contributing intellectual tradition to the emergence of a specifically legal enclave within New Left politics in Australia in the 1970s. The New Left lawyers - a loose, unstructured grouping of practitioners with similar political beliefs about law's negative impacts on the socially marginalised - were broadly interested in the provision of legal services to all citizens denied fair and equal access to its protection. The focus of many of these practitioners was the establishment of community legal centres in inner-city Melbourne and Sydney, in the early 1970s, underpinned by a broader imperative to engage law with the general question of disadvantage, particularly as it related to Indigenous peoples. ${ }^{31}$ In doing so, there

29 See Margaret Thornton, Dissonance and Distrust: Women in the Legal Profession, Oxford University Press, Melbourne, 1996, pp. 73-9; Lorraine Elliot, 'Inequalities in the Australian Education System. Part 2: Women in the Professions' in Mercer, The Other Half.

30 John Chesterman, 'The Making of the Australian New Left Lawyer' (1995) 1 Australian Journal of Legal History 37, 43. For a discussion of the New Left in general, reflecting on their intellectual antecedents and politics, and a contemporaneous assessment of John Anderson's influence on Push politics and agendas, see John Docker, Australian Cultural Elites: Intellectual Traditions in Sydney and Melbourne, Angus and Robertson, Sydney, 1974; Richard Gordon and Warren Osmond, 'An Overview of the Australian New Left' in The Australian New Left: Critical Essays and Strategy, William Heinemann Australia, Melbourne, 1970.

31 In particular, the establishment of the Aboriginal Legal Service in Sydney, in 1972. See, for example: John Basten, 'Legal Services: Looking into the 1980s' (1980) 5(6) Legal Service Bulletin 282-5. Basten's article is an overview of a public meeting held at the Redfern Town Hall on 1 October 1980, organised by the Australian Legal Workers' Group, on the topic 'Legal Services in the Eighties'. The panel consisted of Justice Lionel 
was an implicit recognition of liberal law's contradictions, its claims to provide equal treatment and protection for all and its different standard of delivery of services to different citizens. Despite constructing themselves in opposition to mainstream legal practice and culture, many lawyers who identified as part of the New Left were by default implicated in the process of liberal reformism. Like feminists beginning to find a critical engagement with state doctrine and practice, the left legal community from the early to mid-1970s had to engage with the law to attempt to transform its operation. These efforts showed, at first, a concern with theorising how the law constructed some subjects as disadvantaged to begin with. At the same time, however, they sowed the seeds for understanding some of the epistemological limits of transformative legal critique that were to come in the 1980s. The centres, and the broad philosophy of working collectively and actively through community education as well as the provision of legal services to alter their society, was important at this time as it brought a genuinely pluralist political community within the auspices of legal service provision. Slowly, and correlatively, this broadened thinking about law that started to escape the traditional binds of professional solidarity or formalist jurisprudence about legal subjects that had previously prevailed in Australian legal culture. ${ }^{32}$

The Redfern Legal Centre (RLC) in Sydney provides perhaps the best example of the practicalities of these connections and influences and how they, in turn, impacted on specifically feminist praxis also. ${ }^{33}$ The story of the RLC is of course a distinctly Sydney history. This is, however, important: the micro-histories of people and political organisations, and the philosophies that drive them, in each state are too often glossed over in an attempt to reflect what is perceived to be a national or transnational experience. Often the specificities of time and place contribute greatly to the social contests that influence conceptual developments within discourses such as law; and paradoxically, looking closely at such contests can only help reveal the interplay of ideas and political currents that emerges from international intellectual exchange, and that assists in creating a uniquely national political experience. This is particularly the case, I would

\footnotetext{
Murphy, who initiated the Australian system of legal aid in 1972, when he was Attorney-General of Australia, Mary Gaudron, Chairwoman of the NSW Legal Services Commission, and Paul Coe, Chairman of the NSW Aboriginal Legal Service.

32 Chesterman, 'The Making of the Australian New Left Lawyer', p. 47. The implication that the left legal community of the 1980s was 'non-theoretical' is made contextually. In comparison with the nature of theoretical and critical jurisprudence in the 1990s, the emphasis in the 1980s was placed heavily on securing actionable methods by which citizens could receive access to justice. As the papers to a 1982 conference organised by the Australian Legal Workers' Group indicate, however, a theoretical perspective on these issues was evident. See: John Basten, Mark Richardson, Chris Ronalds and George Zdenkowski, 'The Criminal Injustice System', ALWG and Legal Service Bulletin, with the Law Foundation of New South Wales, Sydney, 1982.

33 For the Victorian history, see: John Chesterman, Poverty Law and Social Change: The Story of the Fitzroy Legal Service, Melbourne University Press, Carlton. Note, however, that the politics of libertarianism was predominantly a Sydney phenomenon.
} 
argue, in relation to recognising gendered embodiment within Australian law. In this prequel to the history of the $S D A$, a close examination of Sydney radical politics that engaged with law in the period before 1984 is important, for the simple fact that many of the people involved in codifying or later analysing that law were part of that political community. They can be viewed, then, as Gilles Deleuze and Felix Guattari suggest, as 'conceptual personae' or 'thought figures' that enable and contribute to social and intellectual genealogy. ${ }^{34}$

Many volunteers at the RLC, about the time of its opening in 1976, were still in law school or had just completed their law degrees. Robyn Lansdowne, later a member of FLAG, reflecting on the initial organisation of that centre, characterised the informing perspectives of its original membership as products of the more radical new law curriculum at the University of New South Wales and of the political climate of 'expansion and optimism'. ${ }^{35}$ There was a sense of energy to harness the changes to legal aid and law reform that had occurred under the Whitlam administration - an administration that had also opened up entry to the legal profession for many through its egalitarian policy on free tertiary education. Other members of the original Redfern Legal Centre Collective brought quite different expectations and experience to this new quest to grant accessible legal services for those who generally fell outside the law's protection. The RLC also drew the involvement of those with libertarian anarchist backgrounds - in particular, the criminal justice collective known as the Prisoners' Action Group (PAG).

Libertarianism in Sydney was idiosyncratic and deeply nihilistic. Influenced by Sydney University philosopher John Anderson, the Sydney Push (as the older-style libertarians identified it) was committed to disrupting traditional notions of morality through lived experience, critiquing the suppression of internal dissent virulent in political organisation and confronting difficult and contradictory aspects of more mainstream, as well as Marxist platforms. That said, the lived experience of flouting mores - the practice of permanent protest - did not translate to direct confrontation of changing the systemic ways in which those cultural mores flourished and were constantly politically perpetuated. For younger members of the Push, the Vietnam War provided a significant break with the ethic of permanent protest as lifestyle. The new group, originally self-titled the Kensington Futilitarians (after the suburb in which the University of New South Wales had been built, which many attended), was less devoted to the philosophical ramparts of the old Push (Reich, Pareto) than to

\footnotetext{
34 Gilles Deleuze and Felix Guattari, What is Philosophy?, Translated by Graham Burchell and Hugh Tomlinson, Verso, London, 1999, p. 73. A similar idea is expressed by Hannah Arendt, Men in Dark Times, Jonathon Cape, London, 1970. I thank Ann Curthoys and John Docker for this point (see Ann Curthoys and John Docker, Is History Fiction?, UNSW Press, Sydney, 2006, p. 10).

35 Genovese, The Battered Body, p. 191. See also John Basten and Robyn Lansdowne, 'Community Legal Centres: Who's in Charge' (1980) 5(2) Legal Service Bulletin 52.
} 
the intellectual movement situationism then emerging in France, and key to the events of May 1968 in Paris. Influenced by the writings of Marx and of Guy Debord, situationists believed in 'subverting accepted norms, in spontaneous and haphazard anarchism, in using art to turn society on its head to reveal the emptiness of public rhetoric' ${ }^{36}$ The Kensington Futilitarians (later Libertarians) were to extend this project, marrying the ethic of haphazard performative anarchism to more concrete struggles (such as the battle to save Victoria Street in Kings Cross from redevelopment, and anti-censorship.) Their political actions inevitably resulted in their own arrests and a personal lived experience of the criminal justice system from the inside, which culminated in the formation of PAG in 1973.

PAG was therefore a unique alliance that would be hard to imagine in our own regulated and politically demarcated times. It included ex-prisoners, UNSW legal academics such as George Zdenkowski and David Brown, libertarians and civil liberties members - all committed to exposing the horrendous conditions in NSW jails. ${ }^{37}$ They wanted to transform the criminal justice system itself, with a long-term goal of abolishing jails altogether, and employed the intellectual framework and street performativeness of situationism to great effect in the politics surrounding the Bathurst Jail riots and Nagle Royal Commission into the NSW prison system in the 1970s. ${ }^{38}$ As a theoretical proposition, PAG advocated "breaking through categorisations of "practitioners", "theoreticians", "political activists" and also acknowledging the different contributions that organizations and individuals can make and the alliances that can be formed around specific issues' (this was of course an important lesson of feminism also). From a criminology/penology perspective, Zdenkowski and Brown also began to refer to the work of Michel Foucault, especially Discipline and Punish (1977), in order to explain the regime of regulation that gave the criminal justice system its sense of authority - adding new intellectual directions for an emerging Marxist/ anarchist critique of criminal law, if not law more generally. ${ }^{39}$

36 Anne Coombs, Sex and Anarchy, Viking/Penguin, Ringwood, Vic., 1996, p. 232. See also John Docker, 'Sydney Intellectual History and Libertarianism' (1972) 7(1) Australian Political Studies Association Journal 42; A. J. Baker, 'Sydney Libertarianism and the Push', Broadsheet, no. 81,(March, 1970), p. 5.

37 Coombs, Sex and Anarchy, pp. 186-7; Ken Buckley, 'Our Meeting With The Premier: The Nagle Report on Prisons', Civil Liberty, no. 79 (July/August, 1978), p. 6; George Zdenkowski, 'Civil Liberty', Civil Liberty, no. 68 (August/September, 1976), p. 4.

38 See generally: Prisoners' Action Group 1976, 'Bathurst Gaol and the Royal Commission into Prisons-A summary by the PAG' (1976) 2(3) Alternative Criminology Journal 142. Their activities included: broadcasting over prison walls; setting up and managing a halfway house for ex-prisoners in Glebe; publishing prison diaries and newsletters through their publishing arm, Breakout; working with trade unions to stop the construction of the maximum-security complex Katingal; and protesting the draconian and vicious imperatives behind the complex itself in the ultimately successful 'Close Katingal Campaign'. See generally: 'Editorial' (1978) 1(9) Jail News.

39 George Zdenkowksi and David Brown, The Prison Struggle: Changing Australia's Penal System, Penguin, Ringwood, Vic., 1982. 


\section{The Embodiment of Crime}

Concomitant with this situationist attack against morality and authority in the criminal justice system there was burgeoning internal conflict within libertarianism itself, which resulted in the formation of a specifically feministfocused prison reform group, in 1973: Women Behind Bars. Key to this development was a student called Wendy Bacon, who had arrived in Sydney in 1966 from Melbourne to study sociology with Sol Encel at the University of New South Wales. Bacon is of course a significant Australian journalist and academic, but at this time she was part of a vanguard of younger women who had been introduced to libertarian philosophy through their social and sexual relationships. They began, however, to challenge the old Push in a different way to their male contemporaries. Although libertarianism in any form appeared to accord women a sense of sexual freedom, and through this an identity that existed outside the cultural constraints imposed on the 1950s and 1960s woman, this freedom was extracted at a price. Like other women in more mainstream New Left politics at the time, whose ideas about feminism emerged from their firsthand experience of misogyny within the constraints of politics allegedly committed to equality, women such as Bacon began to question the terms on which their freedom was granted; their engagement with theories of women's liberation challenged the inherent misogyny of the Push. ${ }^{40}$ It was this kind of cross-fertilisation of experience with ideas that created a new critical perspective for women-centred political action - a perspective that demanded constant and continuous opposition to authority as well as a need for broad social change; and the focus, increasingly, became the operation of the law.

In February 1972, Bacon was put on trial for obscenity charges relating to editing the UNSW paper, Tharunka. (These charges were exacerbated by demonstrating against the summons by parading outside the court wearing a nun's habit emblazoned with the infamous slogan 'I've been fucked by God's steel prick', which if nothing else showcased how disruptively potent a libertarian feminism might be. $)^{41}$ She chose to defend herself in 'an attempt to cut across accepted legal notions of what might be acceptable to an "average man"'. ${ }^{42}$ Despite her efforts, she lost the case and was sentenced to Mulawa Women's Detention Centre for eight days. The experience of being in jail-as it had for those who formed PAG - undeniably sharpened Bacon's political focus and formed the experiential basis for her unfolding commitment to challenging and confronting the operation of the law, which had arguably ever broadening

40 Coombs, Sex and Anarchy, pp. 223-7; Wendy Bacon and Ken Maddock, 'Symposium on Does Women's Liberation Conflict with Human Liberation?', Broadsheet 67, 1971, p. 1.

41 Coombs, Sex and Anarchy, pp. 240-5.

42 Ibid., p. 245. 
implications. On Bacon's release, and alongside women increasingly drawn from the women's liberation movement and, more broadly, the New Left legal community, Women Behind Bars (WBB) was formed. ${ }^{43}$

With a commitment to pluralism across theoretical and activist lines, WBB mirrored PAG. Its original and primary objective was, however, to critique the bases of imprisonment of women. Many women were in jail because they were poor; crimes such as prostitution or fine default were the result of class circumstances. For other women incarcerated for more serious offences, such as murder, manslaughter or infanticide, WBB began to argue that those crimes were precipitated by a history of violence and abuse, which in the face of a lack of other community resources, were played out to tragic ends in women's efforts to free themselves. ${ }^{44}$ These arguments were informed and influenced by the cross-section of WBB members who had also been involved with grassroots feminist campaigns to establish women's refuges-campaigns for service provision that had caused domestic violence to be named and discursively identified as embodied crime for the first time. WBB was committed to arguing against the unequal and discriminatory effects of law as pertaining to women as a class, but was increasingly conscious of the need to make specific the ways in which law - in this case, criminal law and practices - enabled such unequal treatment for women, inscribed through their bodily difference to men and, more intangibly, the male legal subject. ${ }^{45}$

For example, the Bathurst riots in 1975 had illuminated the culture of violence and coercion horrifically enacted on the male prisoner through his body. For women, this level of violence was more insidiously inflicted on their bodies by a withholding of services, as opposed to daily beatings or floggings (although these also occurred). As Bacon mentioned later: 'Women in prison as elsewhere are controlled through their bodies in a very real way. ${ }^{46}$ Realising the extent to which embodiment, and gendered embodiment, rendered the operation of their treatment within prison was significant. In May 1976, WBB applied for and was granted legal aid for representation at the Nagle Royal Commission into NSW prisons. Lawyer Pat O'Shane (later one of Australia's first Indigenous

\footnotetext{
43 Wendy Bacon, The Anne Conlon Memorial Lecture, NSW Women's Advisory Council, Sydney, 1983, pp. $17-18$.

44 Wendy Bacon, 'Women in Prisons', Refractory Girl, May, 1985, p. 2; Sandra Willson, 'Behind Bars' in Judy Mackinolty and Heather Radi (eds), In Pursuit of Justice: Australian Women and the Law 1788-1979, Hale \& Iremonger, Sydney, 1979, pp. 173-6; Women Behind Bars, 'Who is in Gaol and Why are they There?', Women Behind Bars (A Summary of Activities), 1983, Women Behind Bars, Sydney; The First Ten Years of Sydney Women's Liberation Collection, ML 388/81.

45 See also Anonymous, 'Prison Justice', Sydney Women's Liberation Newsletter, May, 1977, p. 7. Women Behind Bars, 'Women Behind Bars' (1976) 1(3) Alternative Criminology Journal, 21-2 (reprinted from Mabel, December, 1975); Willson, 'Behind Bars', p. 172.

46 Bacon, The Anne Conlon Memorial Lecture, p. 18.
} 
magistrates) was employed to present the group's case. ${ }^{47}$ The main focus of the submission was the inadequate medical treatment available to women in Mulawa. In July 1976, WBB held a demonstration outside the jail to highlight the nature of the complaints being prepared for the commission. A long banner with the words 'Mulawa Jail makes women sick' was stretched along the fence and a tape of medical information was broadcast for the benefit of the women inside. In 1976, WBB was successful in having its submission to the Nagle Royal Commission accepted as the basis for recommendations for reform. ${ }^{48}$ That said, the campaign to improve medical treatment for women prisoners in New South Wales illuminated the distinct and somewhat contradictory character of WBB. The incursion of women from outside the original libertarian membership, from women's liberation and from the New Left legal community, and the nature of campaigns that showed clearly the need to confront law itself, ensured that the group began to have a reformist agenda inscribed on an anarchist foundation. This cross-fertilisation gave impetus to an increasingly critical focus on the negative, and adversely experienced, particulates of gendered difference inherent within the prison system and how those differences effected the unequal operation of criminal justice for men and women.

Wendy Bacon might have initially gone to jail, and been awakened to the injustice of the criminal justice system, because of an anti-authoritarian act that implicitly critiqued the practices of the law. Her journey, however-in some senses the journey of many women with radical political perspectives writ small-led her to a dissonant engagement with liberal reformism as an intellectual project. By 1978, Bacon had enrolled as a law student, and, along with Robyn Lansdowne, part of the New Left legal community, had been employed as a researcher by FLAG - Australia's first feminist collective committed to confronting gendered difference as experienced and also proscribed, and therefore as a paradoxical concept in the broader legislative project of getting equal.

\section{An Australian Feminist Legal Praxis}

In August 1978, at Sydney University, an academic conference dedicated to thinking about the possibilities suggested for feminism and law was held for the first time. The Australian Women and Law Conference drew participants

\footnotetext{
47 Women Behind Bars, 'Legal Visits to Mulawa' and 'Mulawa Jail Makes Women Sick', Sydney Women's Liberation Newsletter, May, 1977; Bacon, 'Women in Prisons', p. 7.

48 J. F. Nagle, Report of the Royal Commission into New South Wales Prisons. Volumes I, II and III, NSW Government Printer, Sydney, 1978, Recommendations 187-99. These included: the provision of antenatal and gynaecological treatment for all women prisoners; the relaxation of the practice of forcing mothers to surrender infants on their first birthday; the improvement of medical facilities; and the movement of psychiatric patients to more appropriate care. See also: Women Behind Bars, 'Demonstration at Mulawa' (1976) 1(4) Alternative Criminology Journal 71-2.
} 
from history, sociology and, more tentatively, law. The conference covered a wide range of topics - from domestic violence, lesbian custody cases and a discussion of the recently introduced Family Law Act1975 (Cth) to more historically grounded analyses of citizenship, professional legal participation and colonial law. ${ }^{49}$ The number of women involved who had also been involved in early women's liberation campaigns was considerable. These women - a disproportionate number of whom were historians or postgraduate students in history (such as Anne Summers and Lyndall Ryan) - had instigated journals and newspapers such as Refractory Girl and Mejane and were themselves influential in developing a burgeoning theoretical focus on the nature of liberation, then feminism, itself. ${ }^{50}$ The conference was the first conscious attempt within the nascent academic arm of Australian feminism to conduct an interdisciplinary forum on the development and operation of law as it affected women in contemporary Australian society. Lesley Lynch, in reviewing the conference for Refractory Girl, noted with interest and a clear sense of theoretical separation the focus and visibility of the 'new breed of feminist legal women'. Her reaction to them as a group was ambivalent:

On the one hand I was admiring, even envious, of the talent, energy and more particularly of the confident optimism; on the other I was uneasy about what appeared to be the prevailing world view. It might just be the hoary old tension between the pragmatism of reform and revolution making, but I detected an unhealthy respect for the overall legal system...[T]hey seemed to regard this structure too reverentially. ${ }^{51}$

The talented young women starting to emerge within the legal profession at this time, and becoming inculcated into the procedural language and practice of the law, were not of course without theoretical or critical voice. As O'Connor's submission to the Women's Commission in 1975 indicates, there was an awareness among New Left lawyers of the form of disadvantage imposed on women as legal subjects by the law's instrumental bias and lack of recognition of their political equality, and of their claims to entrench that equality within other spheres, however cautiously that extended to theorising about the normative biases within law itself. As Lynch also observed, 'it must be difficult being both a lawyer and a feminist'. ${ }^{52}$

In July 1978, however, one month before the conference, Margaret Thornton, a recent graduate of the new and progressive law school at the University of New South Wales, and Joan Bielski of the WEL, sent a joint circular letter to call

49 Lesley Lynch, 'Women and Law Conference', Refractory Girl, March, 1979, p. 35.

50 Ann Curthoys, 'Visions, Nightmares, Dreams: Women's History, 1975' (1996) 27(6) Australian Historical Studies 1.

51 Lynch, 'Women and Law Conference', p. 35.

52 Ibid. 
together a meeting of women interested in the law. ${ }^{53}$ Despite the existence of a professional body for female practitioners (the Women Lawyers' Association) and despite the committed left praxis emerging from the community legal centre movement, Thornton and Bielski saw the need for a collective and organised group that 'did something for women in general'. The US group Women's Equity Action Lobby (WEAL) provided both a framework and an inspiration as a feminist group committed to researching and proposing legislation that affected women and developing test cases on women's rights. ${ }^{54}$ Thornton and Bielski perceived the group-like the approach to pluralist membership of groups within the left in general at this time - to be inclusive of a wide range of women, not merely those within the legal profession, and directed their original circular to students and non-lawyers as well as practitioners. The group's members emerged from the New Left legal community - groups such as WBB, the refuge movement, WEL and broadly aligned women's liberationists. In keeping with this open spirit and the recognition of the need to draw together women with a wide range of perspectives and skills, 'lawyers' was carefully avoided in the process of naming the group (although in sharp contrast with today's political conservatism, 'feminist' was included). They called themselves the Feminist Legal Action Group (FLAG). In these terms, FLAG consciously constituted itself as a reactive body committed to investigating and researching from a multiperspective basis what the law meant to women and how it controlled them. ${ }^{55}$

From the first meeting of FLAG (held in the boardroom of Coonan and Hughes) it was evident that the range of perspectives on the law brought from members trained in social work, counselling and grassroots politics, as well as law, meant that the group's aims and objectives stretched beyond ad-hoc, issue-by-issue campaigns directed towards instrumental law reform. ${ }^{56}$ This was to be achieved practically through a range of actions. For example, FLAG perceived some of its short-term aims to be giving expert evidence at public hearings that related to women, commenting on legislation under consideration (specifically the Anti-Discrimination Act 1977 [NSW]) and compiling a directory of lawyers sympathetic to women. ${ }^{57}$ (As noted in a FLAG information sheet in 1979, 'an incipient directory exists but suffers from a dearth of lawyers with feminist

\footnotetext{
53 FLAG announced its formation at the conference: Lynch, 'Women and Law Conference' 36; Thornton, Dissonance and Distrust, pp. 213-15; Ross, 'F.L.A.G.' 123.

54 Ross, 'F.L.A.G.'.

55 Ibid., p. 123; Letter, Margaret Thornton to Sue Wills, 7 August 1991, The First Ten Years of Sydney Women's Liberation Collection, ML 388/81. Thornton also noted: 'I do remember an early meeting involving a ubiquitous discussion (maybe less so now) as to whether the word "feminist" should be included in the title or not. Some were opposed as it would be "too threatening" to the law reform bodies etc to which we proposed to make submissions.'

56 By 1979, it was noted that membership was drawn from a minority of practitioners, many legally qualified but non-practising women, a number of law students and many other women drawn from education, sociology, counselling and social work (Ross, 'F.L.A.G.').

57 Thornton to Wills, 7 August 1991; Ross, 'F.L.A.G.'. 123.
} 
sympathies'.) f $^{58}$ FLAG's longer-term objective was to conduct research into women's treatment by the law. This research-based focus was something new. It was to be the diversity of women who designed, executed and engaged with this idea of understanding through research how gender was conceptualised by law, with what reasons and with what effects, that opened up the space for a specifically Australian feminist legal praxis, which moved beyond the specificity of this group and of which the $S D A$ became a beacon example.

Between July 1978 and June 1979, for example, FLAG worked on a number of small projects focusing on child welfare, family law and anti-discrimination. The major project initiated by the group, however, and the one that was to raise FLAG's profile within both the community of lawyers and legal reformers and the broader public, was their funded research on women convicted of homicide in New South Wales. ${ }^{59}$ The wide objective behind the homicide project was to 'build up the presently deficient body of research relating to women and the law', ${ }^{60}$ and the two researchers chosen to undertake this task, supervised by sociologist Roslyn Omodei, were Robyn Lansdowne and Wendy Bacon. Lansdowne, as a graduate lawyer involved with the Redfern Legal Centre, brought skill and political conviction to the task of law reform inherent in such a project. Bacon's involvement evidenced her continuing political commitment to find new methods for exposing the injustice of the prisons, which, in a libertarian sense, inappropriately incarcerated women for crimes derived from their own social dislocation. ${ }^{61}$ The FLAG homicide report that resulted from their efforts was a watershed in Australian research into the law's treatment of women for several reasons, not least of which was the fact that it resulted from the synthesis of political and cultural currents operating within feminism and the wider political community at the time. Research undertaken before the FLAG report on homicide in New South Wales had followed a traditional statistical sociology/criminology methodology. ${ }^{62}$ The FLAG report instead eschewed traditional criminological readings of offending women (analyses based objectively on their biology and psychology), preferring to investigate the subjective characteristics of each crime and the embodied experiences of each perpetrator. In accord with the political ethic of articulating the personal as political drawn from the women's liberation movement, female homicide offenders were interviewed to ascertain the personal histories that precipitated

58 FLAG, The First Ten Years of Sydney Women's Liberation Collection, ML 388/81; Ross, 'F.L.A.G.'.123.

59 Wendy Bacon and Robyn Lansdowne, Feminist Legal Action Group Report: Women Homicide Offenders in NSW, Feminist Legal Action Group, Sydney, 1982, pp. 44-5.

60 Ross, 'F.L.A.G.'.

61 Bacon, The Anne Conlon Memorial Lecture.

62 See, for example, the work undertaken in the field before the FLAG report: Therese Rod 1979, Murder in the Family in New South Wales 1958-1967, Master of Arts thesis, University of Sydney, NSW. For an explanation of the FLAG agenda and methodology, see Bacon and Lansdowne, Feminist Legal Action Group Report, pp. 8, 11-13, 26-8. 
their crimes. The authors' view was that 'more insight is to be gained by seeing these women's acts as explicable in the light of their social and family situations than as expressions of individual deviance'. Overwhelmingly, the hidden experience of domestic violence, and women's inability to access avenues of assistance to free themselves, dominated the findings.

The wider effects and results of this research, which spearheaded and shaped the first successful challenge to the provocation defence in any Australian State, through the case of Violet and Bruce Roberts, I have written about elsewhere. ${ }^{63}$ It is important to highlight in this context that the FLAG report, and the group itself, was of crucial importance in a developing feminist legal theory, as it pushed the boundary of a Marxist analysis of the law (in which women were constituted as a single, albeit disadvantaged class). Feminist thinkingespecially about criminal law - could now also incorporate consideration of how law exerts power over women through a mythical objective ontology, yet correlatively subsumes the conceptual force of gender as diversely constituted and subjectively experienced. ${ }^{64}$ Through the use of theoretically grounded and conceptualised research in specifically targeted legislative and community campaigning to force public recognition of the specificities of women's differences to men through this particular aspect of criminal law, FLAG also managed to challenge the bases on which law reform for and by women could be conceived. The pluralism of FLAG, evidenced through the Bruce and Violet Roberts campaign, knowingly combined reformist and activist skills and practical legal and theoretical positions on law reform. The group's formation and that particular project and its outcomes both demonstrated and exemplified, then, that a specifically critical feminist approach to law reform was possible. It also clearly identified that the pluralist politics of the feminist community, rather than a strictly lego-centric (law-centred) approach, was inherent in the exposure of the limits and contradictions of how gender was conceived of as a normative concept within law. This combination was to have significant consequencesnot only for bringing the plight of the battered woman who kills to the attention of the wider public and in forcing legislative change in the light of common law intransigence (a question that dominated the feminist legal agenda in the 1980s and 1990s in Australia), but for broadening the parameters of feminist critical thinking about the law itself.

63 Genovese, The Battered Body.

64 Other work contributing to this shift in thinking about criminal law by feminists includes: Satyanshu K. Mukherjee and Jocelynne A. Scutt (eds), Women and Crime, George Allen \& Unwin for Australian Institute of Criminology, Sydney, 1981. 


\section{Feminist Legal Thinking and Gendered Discrimination}

It was not until the mid-1980s, then, concomitant with and broadly declared through the $S D A$, that an independent legal theory was fully articulated in the Australian feminist movement, as well as in the academic and legal circles, and beyond. ${ }^{65}$ This specifically feminist legal thinking, influenced by similar intellectual shifts in the United States and the United Kingdom, asked questions, as Jenny Morgan has put it (echoing Scott), of 'how the law comes to know about women, and what women know' ${ }^{66}$ This kind of questioning, as Margaret Thornton noted in her own influential 1986 essay, was about recognising that paradox was always present in languages of discrimination, rights or equality for women. By the mid-1980s, this problem could be seen retrospectively as constantly present and under negotiation in all the feminist campaigns that had challenged domestic law to that date - not the least of which had been the work of and through FLAG around provocation. By the 1980s, as Thornton then elaborated in The Liberal Promise (1990) and Morgan and Graycar argued in their The Hidden Gender of Law (1990), it was possible to theorise from experience, research and philosophy that law was epistemologically constrained by its own systems of rationality and coherence. Law had great difficulty accepting a differentiated, sexed subject, bounded by legal and deeply held historical assumptions of corporeality, and hence social location and visibility. The choices for feminists wishing to open access for women within law's boundaries, and at the same time to recognise and contest those boundaries, by 1984 were perceived as constrained, and as always offering a compromised negotiation. To paraphrase political theorist Wendy Brown, any scrutiny by feminists of how gender is discursively constructed makes possible certain arguments about women's equality, yet forecloses others. ${ }^{67}$

65 Texts such as Ngaire Naffine, Law and the Sexes: Explorations in Feminist Jurisprudence, Allen \& Unwin, Sydney, 1990; Regina Graycar and Jenny Morgan, The Hidden Gender of Law, Federation Press, Leichhardt, NSW, 1990, and Thornton's The Liberal Promise (also published in 1990) began to question the theoretical, as opposed to merely substantive, ways in which liberal law was built on claims to objectivity, neutrality as truth that denied recognition of women as a subject differentiated from the rational, benchmark 'reasonable man'. The questions raised in these texts - refracting and reflecting similar developments overseas - therefore acted as the 'next phase' of feminist legal thinking, building on the foundations of the focus in the fight for equal recognition, which dominated the feminist legal agendas of the early 1970s. They began to ask questions that attempted to understand women's difference as a tool for critique, even when this critique was inscribed on the binary conceptions of women that underpinned legal doctrine, and although in conversation with US, Canadian and British feminist legal scholars were importantly directed towards analysing a national experience and practice of law. For an analysis of this theoretical progression, see: Ngaire Naffine 1993, 'Assimilating Feminist Jurisprudence' (1993) 11 Law in Context 78.

66 Morgan, 'Women and the Law', p. 116; and generally Morgan and Graycar, The Hidden Gender of Law.

67 Brown, 'Tolerance as Supplement', p. 50. 
This defining conundrum of feminist legal theory is embedded in the SDA. On the one hand, the purpose of the Act was about providing individual as opposed to collective avenues to legal address for harms caused in the workplace. ${ }^{68}$ As Thornton has argued, this both reinforces legal liberalism's a priori assumptions about individual subjects - a benchmark man - and cordons off the domestic sphere from scrutiny by the Act. The legislation therefore 'effectively legitimises the public/private dichotomy of liberalism' ${ }^{69}$ Importantly, however, the SDA also recognised legislatively that harms occurred to women in a specifically embodied way because of their difference, inherently critiquing the dichotomised thinking of law through the indirect discrimination and sexual harassment provisions, and offering a gendered critique to law's construction and operation. One of the most significant achievements that can be identified in the $S D A$ is that this paradox was implicitly recognised, but still formulated through legislation, despite the kinds of resistance articulated by Lesley Lynch in 1978 lingering within the feminist community at large. And, perhaps most importantly, this paradox was articulated by lawyers who also happened to be part of that much broader, diverse women's movement, emboldened by both intellectual critique of equality as offering negative and positive capabilities for women and a radical turn to situated, frontline engagement, unafraid of tackling sex as a differential.

Discrimination as a gendered concept in our law has therefore a complex past that cannot be reduced to what Scott identifies as fixity of historical gaze. A history must be interpolated through and by a multivalent, dissonant, sometimes maverick synthesis of feminist traditions and practices of the 1970s period of activism and theorising. What is clear is that the complex politics that led to the $S D A$ not only incorporated the visions and skills of women who had infiltrated and upset the balance of the administration of the state (such as Susan Ryan) but also the more curious and somewhat slower articulation by other women of a jurisprudence of equality and difference that emerged through feminist legal theory and activism. The origins of the SDA should therefore read these histories of feminism of the 1970s and 1980s as complementary. Together, they open up spaces for different aspects of the conceptual as well as socialhistorical understanding of what was included in the Act in 1984, and whyand what was excised into affirmative action legislation. Such a history also, perhaps, offers ways of thinking, culturally and politically, about what remains unsaid about sexed discrimination in this country - the as yet unacknowledged legislation of an Equality Act, or the unheeded assumptions of future human rights instruments.

68 Ronalds, this volume.

69 Margaret Thornton, 'Equal Rights at Work' in Barbara Caine (ed.), Oxford Companion to Australian Feminism, Oxford University Press, Melbourne, 1998, p. 87. 
Importantly, too, this short prehistory aims to caution against forgetting any of those origins, or conflicts, through which an Australian feminist legal thinking could be articulated. Despite the threats in the contemporary moment to the politics of naming and speaking questions of 'how the law comes to know about women, and what women know', it is easy to forget that Australian legal feminism was never lego-centric. It was never a praxis isolated within the profession or uncontaminated by intellectual challenges extant to traditional jurisprudence. Hard-fought skirmishes by lawyers over instruments such as the $S D A$, since 1984, by necessity, although inadvertently, narrow the political focus to legal discourse and experience. By remembering what the feminist legal community might have lost sight of in that process - the multiple, interconnected and often radical histories of how Australian feminism contested the public sphere - can only enliven law as a politics for present challenges, including, but not limited to, those about gendered discrimination.

\section{Bibliography}

\section{Books and articles}

Anonymous, 'Prison Justice', The Sydney Women's Liberation Newsletter, May, 1977, p. 7.

Arendt, Hannah, Men in Dark Times, Jonathon Cape, London, 1970.

Armstrong, Susan, 'Is Feminist Law Reform flawed? Abstentionists \& Sceptics' (2004) 20 Australian Feminist Law Journal 43.

Attwood, Bain and Markus, Andrew, The 1967 Referendum: Race, Power and the Australian Constitution, Second edition, Aboriginal Studies Press, AIATSIS, Canberra, 2007.

Bacon, Wendy, Anne Conlon Memorial Lecture, NSW Women's Advisory Council, Sydney, 1983.

Bacon, Wendy, 'Women in Prisons', Refractory Girl, May, 1985, p. 2.

Bacon, Wendy and Lansdowne, Robyn, Feminist Legal Action GroupReport: Women Homicide Offenders in NSW, Feminist Legal Action Group, Sydney, 1982.

Bacon, Wendy and Maddock, Ken, 'Symposium on Does Women's Liberation Conflict with Human Liberation?', Broadsheet, no. 67 (1971), pp. 1-5. 
Baker, A. J., 'Sydney Libertarianism and the Push', Broadsheet, no. 81 (March, 1975), pp. 5-10.

Basten, John 1980, 'Legal Services: Looking into the 1980s' (1980) 5(6) Legal Service Bulletin 282-5.

Basten, John and Lansdowne, Robyn, 'Community Legal Centres: Who's in Charge' (1980) 5(2) Legal Service Bulletin 52.

Basten, John, Richardson, Mark, Ronalds, Chris and Zdenkowski, George, 'The Criminal Injustice System', ALWG and Legal Service Bulletin, with the Law Foundation of New South Wales, Sydney, 1982.

Brown, Wendy, 'Tolerance as Supplement: 'The "Jewish Question" and the 'Woman Question"' in Regulating Aversion: Tolerance in the Age of Identity and Empire, Princeton University Press, NJ, 2008.

Buckley, Ken, 'Our Meeting with the Premier. The Nagle Report on Prisons', Civil Liberty, no. 79 (July/August, 1978), pp. 6-7.

Chesterman, John, 'The Making of the Australian New Left Lawyer' (1995) 1 Australian Journal of Legal History 37.

Chesterman, John, Poverty Law and Social Change: The Story of the Fitzroy Legal Service, Melbourne University Press, Carlton, 1996.

Coombs, Anne, Sex and Anarchy, Viking/Penguin, Ringwood, Vic., 1996.

Curthoys, Ann, 'Visions, Nightmares, Dreams: Women's History, 1975' (1996) 27(6) Australian Historical Studies 1.

Curthoys, Ann and Docker, John, Is History Fiction?, UNSW Press, Sydney, 2006.

Deleuze, Gilles and Guattari, Felix, What is Philosophy?, Translated by Graham Burchell and Hugh Tomlinson, Verso, London, 1999.

Docker, John, 'Sydney Intellectual History and Libertarianism' (1972) 7(1) Australian Political Studies Association Journal 42.

Docker, John, Australian Cultural Elites: Intellectual Traditions in Sydney and Melbourne, Angus and Robertson, Sydney, 1974.

Elliot, Lorraine, 'Inequalities in the Australian Education System: Part 2: Women in the Professions' in Jan Mercer (ed.), The Other Half: Women in Australian Society, Penguin, Ringwood, Vic., 1975. 
Genovese, Ann, The Battered Body: A Feminist Legal History, PhD thesis, University of Technology, Sydney, $1998<$ utsescholarship.lib.uts.edu.au/ dspace/handle/2100/276>

Gordon, Richard and Osmond, Warren, 'An Overview of the Australian New Left' in The Australian New Left: Critical Essays and Strategy, William Heinemann Australia, Melbourne, 1970.

Graycar, Regina and Morgan, Jenny, The Hidden Gender of Law, Federation Press, Leichhardt, NSW, 1990.

Grimshaw, Patricia, Lake, Marilyn, McGrath, Ann and Quartly, Marian, Creating a Nation 1788-2007, Second edition, API Network, Perth, 2007.

Grosz, Elizabeth, 'The In(ter)vention of Feminist Knowledges' in Barbara Caine, E. A. Grosz and Marie de Lepervanche (eds), Crossing Boundaries: Feminism and the Critique of Knowledges, Allen \& Unwin, Sydney, 1988.

Hunter, Rosemary, Indirect Discrimination in the Workplace, Federation Press, Leichhardt, NSW, 1992.

Jail News, 'Editorial' (1978) 1(9) Jail News..

Lahey, Kathleen, ‘Until Women Themselves Have Told All That They Have To Tell' (1985) 23 Osgoode Hall Law Journal 519.

Lake, Marilyn, Getting Equal:The History of Australian Feminism, Allen \& Unwin, St Leonards, NSW, 1999.

Lanteri, Anne Maree, 'Woman and the Law' in Jan Mercer (ed.), The Other Half: Women in Australian Society, Penguin, Ringwood, Vic., 1975.

Lloyd, Genevieve, The Man of Reason: 'Male' and 'Female' in Western Philosophy, Methuen, London, 1984.

Lynch, Lesley, 'Women and Law Conference', Refractory Girl, March, 197935.

Mackinnon, Catherine A., Sexual Harassment of Working Women, Yale University Press, New Haven, Conn., 1979.

Mackinnon, Catherine A., Feminism Unmodified: Discourse on Life and Law, Harvard University Press, Cambridge, Mass., 1987.

Mason, Gail and Chapman, Anna, 'Defining Sexual Harassment: A History of the Commonwealth Legislation and its Critiques' [2003] Federal Law Review 6 .

Mathews, Jane, 'Women in the Law' (1991) 41 Refractory Girl 27. 
Morgan, Jenny, 'Women and the Law' in Refractory Girl Collective (eds), Refracting Voices: Feminist Voices from Refractory Girl, Southwood Press, Sydney, 1993.

Mukherjee, Satyanshu K. and Scutt, Jocelynne A. (eds), Women and Crime, George Allen \& Unwin for Australian Institute of Criminology, Sydney, 1981.

Naffine, Ngaire, Law and the Sexes: Explorations in Feminist Jurisprudence, Allen \& Unwin, Sydney, 1990.

Naffine, Ngaire, 'Assimilating Feminist Jurisprudence' (1993) 11 Law in Context 78.

Prisoners' Action Group (PAG), 'Bathurst Gaol and the Royal Commission into Prisons: A summary by the PAG' (1976) 2 (3) Alternative Criminology Journal 142.

Reid, Elizabeth and Altman, Denis, Equality: The New Issues, Fabians' Winter Lecture Series: Equality under Labor, Victorian Fabian Society, Melbourne, 1973.

Rod, Therese, Murder in the Family in New South Wales 1958-1967, Master of Arts thesis, University of Sydney, NSW, 1979.

Ross, Kim, 'F.L.A.G.' (1979) 4(3) Legal Services Bulletin 123.

Sawer, Marian, The Ethical State?, Melbourne University Press, Carlton, 2003.

Sawer, Marian, Making Women Count: A History of the Women's Electoral Lobby in Australia, UNSW Press, Sydney, 2008.

Scott, Joan W., 'Gender: A Useful Category of Historical Analysis' (1986) 91(5) American Historical Review 1053.

Scutt, Jocelynne, 'Legislating for the Right to be Equal: Women, the Law and Social Policy' in Cora Baldock and Bettina Cass (eds), Women, Social Welfare and the State in Australia, Allen \& Unwin, Sydney, 1988.

Smart, Carol, Feminism and the Power of Law, Routledge, London, 1989.

Thornton, Margaret, 'Feminist Jurisprudence: Illusion or Reality?' (1986) 3 Australian Journal of Law \& Society 5.

Thornton, Margaret, The Liberal Promise: Anti-Discrimination Legislation in Australia, Oxford University Press, Melbourne, 1990.

Thornton, Margaret 1991, 'Feminism and the Contradictions of Law Reform' (1991) 19 International Journal of the Sociology of Law 453. 
Sex Discrimination in Uncertain Times

Thornton, Margaret, Dissonance and Distrust: Women in the Legal Profession, Oxford University Press, Melbourne, 1996.

Thornton, Margaret, 'Equal Rights at Work' in Barbara Caine (ed.), The Oxford Companion to Australian Feminism, Oxford University Press, Melbourne, 1998.

Thornton, Margaret, 'Neoliberal Melancholia: The Case of Feminist Legal Scholarship' (2004) 20 Australian Feminist Law Journal 7.

Willson, Sandra, 'Behind Bars' in Judy Mackinolty and Heather Radi (eds), In Pursuit of Justice: Australian Women and the Law 1788-1979, Hale \& Iremonger, Sydney, 1979.

Wollstonecraft, Mary, A Vindication of the Rights of Woman, Penguin Books, Harmondsworth, UK, 1982 [1792].

Women Behind Bars (WBB), 'Women Behind Bars' (1976) 1(3) Alternative Criminology Journal 21-2 [reprinted from Mabel, December 1975].

Women Behind Bars (WBB), 'Demonstration at Mulawa' (1975) 1(4) Alternative Criminology Journal 71.

Women Behind Bars (WBB), 'Legal Visits to Mulawa' and 'Mulawa Jail Makes Women Sick', Sydney Women's Liberation Newsletter, May, 1977.

Zdenkowski, George, 'Civil Liberty', Civil Liberty, no. 68 (August/September, 1976), pp. 4-6.

Zdenkowksi, George and Brown, David, The Prison Struggle: Changing Australia's Penal System, Penguin, Ringwood, Vic., 1982.

\section{Legislation}

Anti-Discrimination Act 1977 (NSW)

Prohibition of Discrimination Act 1966 (SA)

Sex Discrimination Act 1975 (SA)

Sex Discrimination Act 1984 (Cth)

\section{Cases}

Australian Iron \& Steel v Banovic (1989) 168 CLR 165

Koowarta v Bjelke-Petersen (1982) 34 ALR 417 
Nadjovska $v$ Australian Iron \& Steel (1985) EOC 92-140

O’Callaghan v Loder (1984) EOC 92-023

O'Callaghan v Loder (1984) EOC 92-024

\section{Reports and miscellaneous primary sources}

FLAG 'Information sheet', 1979, The First Ten Years of Sydney Women's Liberation Collection, Mitchell Library, Sydney, MS388/81.

Letter, Margaret Thornton to Sue Wills, 7 August 1991, The First Ten Years of Sydney Women's Liberation Collection, Mitchell Library, Sydney, MS388/81.

Nagle, J. F., Report of the Royal Commission into New South Wales Prisons. Volumes I, II and III, NSW Government Printer, Sydney, 1978 [Nagle Report].

O'Connor, Deirdre, Should the Women's Movement rely on Law Reform as a Major Weapon in their Struggle?, Unpublished paper, Women's Commission, Sydney, The First Ten Years of Sydney, 1975, Women's Liberation Collection, Mitchell Library, Sydney, MS388/81.

Women Behind Bars, 'Who is in Gaol and Why are they There?', Women Behind Bars (A Summary of Activities), Sydney, 1983, The First Ten Years of Sydney Women's Liberation Collection, Mitchell Library, Sydney, MS388/81.

Women's Trade Union Commission, Women's Unions, Booklet, Sydney, 1976, The First Ten Years of Sydney Women's Liberation Collection, Mitchell Library, Sydney, MS388/81. 